\title{
Kerjasama Selatan-Selatan dan Triangular Sebagai Instrumen Peningkatan Peran Indonesia di Tingkat Global
}

\author{
Stanislaus Risadi Apresian \\ Program Studi Ilmu Hubungan Internasional,Universitas Katolik Parahyangan \\ Email: risadiapresian@gmail.com
}

\begin{abstract}
Abstrak
Kerjasama Selatan-Selatan dan Triangular (KSST) bukanlah isu baru bagi Indonesia.Sejak Konperensi Asia Afrika (KAA) diselenggarakan pada tahun 1955 di Bandung, saat itulah Indonesia sudah memulai kebijakan kerjasama selatan-selatan. Hingga saat ini berarti sudah 60 tahun lebih Indonesia bergelut dengan kebijakan kerjasama selatan-selatan dan triangular ini.Meskipun demikian, masih ada banyak masalah dalam pengimplementasian kebijakan ini. Tidak semua orang Indonesia memahami isu KSST ini atau perlunya memberikan bantuan ke negara sedang berkembang yang lain sementara masih banyak permasalahan pembangunan di dalam negeri. Tulisan ini bertujuan untuk menganalisa mengapa Indonesia memberikan bantuan luar negeri melalui skema KSST. Selain itu tujuan ini juga bertujuan untuk mengidentifikasi hambatan dan tantangan Indonesia dalam mengimplementasikan KSST. Tulisan ini akan menggunakan pendekatan liberal-institusionalisme untuk memahami dan menganalisa isu KSST ini. Keterlibatan Indonesia dalam G20 akan diangkat sebagai studi kasus dalam tulisan ini untuk menemukan jawabab mengapa Indonesia mau memberikan bantuan luar negeri melalui skema KSST, tentunya dengan menggunakan pandangan Liberalis-Institusionalisme. Argumen utama dari tulisan ini adalah Indonesia dapat menciptakan mutual gain melalui skema KSST dan memberikan kontribusi positif dalam mewujudkan kepentingan kolektif dari anggota G20 untuk meningkatkan kesejahteraan global.
\end{abstract}

Kata kunci: kerjasama selatan-selatan dan triangular (KSST), bantuan luar negeri, indonesia, liberalinstitusionalisme, kepentingan kolektif

\begin{abstract}
South-South and Triangluar Cooperation (SSTC) is not a new issue for Indonesia. Indonesia has begun south-south cooperation policy since Asia Africa Conference held in Bandung in 1955.It means that Indonesia has experienced in SSTC for 60 years. Nevertheless, there are still many problems in implementing this policy. Not every Indonesian understand about this issue or the need of giving aid to other developing countries while there are still many development problems occurring in domestic level. This study is aimed to analyze why Indonesia giving overseas development aid through SSTC scheme and to identify the obstacle and challange of Indonesia in implementing SSTC. This study will use liberal-institutionalism approach in order to understand and to analyze the issue. Indonesia involvement in G20 will be discussed as a case study to find the anwer of why Indonesia giving ODA through SSTC. The main argument of this study is that Indonesia will create mutual gain through SSTC and give positive contribution in realizing collective interest of G20 members to improve global prosperity.
\end{abstract}

Keywords: south-south and triangular cooperation (SSTC), overseas development aid (ODA), indonesia, liberal institutionalism, and collective interest

\section{Pendahuluan}

\section{Kerjasama Selatan-Selatan dan}

Triangular bukanlah isu baru bagi Indonesia.

Sejak Konperensi Asia Afrika (KAA)

diselenggarakan pada tahun 1955 di Bandung, saat itulah Indonesia sudah memulai kebijakan kerjasama selatan-selatan. Hingga saat ini berarti sudah 60 tahun lebih Indonesia bergelut dengan kebijakan kerjasama selatan-selatan dan triangular ini. Dengan melakukan kebijakan KSST Indonesia telah memberikan banyak 
bantuan kepada negara-negara selatan. Ternyata Indonesia bukan negara yang hanya menerima bantuan dari lembaga donor, tetapi Indonesia juga mampu menjadi negara donor. Jangan dibayangkan Indonesia memberikan bantuan dana dalam jumlah besar seperti yang dilakukan oleh Amerika Serikat, Australia, Inggris atau Jepang. Bantuan yang sering diberikan oleh Indonesia adalah bantuan dalam bentuk pengembangan kapasitas melalui pelatihan. Meskipun bantuan yang diberikan bukan dalam bentuk uang, tetapi bantuan tersebut tidak boleh dikesampingkan begitu saja karena bantuan tersebut memiliki arti penting bagi peningkatan Kerjasama Selatan-Selatan. Selain itu bantuan luar negeri juga memiliki arti penting bagi peningkatan citra Indonesia dalam kancah internasional. Bantuan luar negeri dapat menjadi alat untuk melakukan diplomasi Indonesia ke negara-negara selatan.

Menyadari pentingnya bantuan luar negeri sebagai salah satu alat untuk melakukan diplomasi bagi Indonesia, maka seharusnya kebijakan bantuan luar negeri ini menjadi salah satu prioritas yang menjadi perhatian pemerintah Indonesia. Pada kenyataannya isu bantuan luar negeri ini baru mendapat perhatian khusus dari pemerintah pada tahun 2010 yang lalu yaitu ketika dibentuknya Tim Koordinasi Nasional yang khusus menangani KSST. Jika melihat sejarah panjang kerjasama selatan-selatan yang pernah dilakukan Indonesia sejak KAA, maka langkah Indonesia ini tergolong sangat terlambat karena seharusnya Tim Koordinasi Nasional ini dibentuk sejak dulu untuk mengkoordinasikan dan mendokumentasikan bantuan-bantuan Indonesia ke luar negeri.

Bantuan luar negeri dapat menjadi alat diplomasi yang efektif namun juga seringkali menjadi kebijakan yang dapat memicu perdebatan karena tentunya tidak semua pihak setuju dengan kebijakan memberikan bantuan untuk negara lain. Permasalahan pembangunan masih banyak ditemui oleh masyarakat Indonesia mulai dari kemiskinan, pengangguran, dan infrastruktur yang kurang memadai khususnya di wilayah pedalaman di Indonesia. Selama masih ada banyak permasalahan pembangunan yang dialami oleh masyarakat Indonesia, kebijakan bantuan luar negeri untuk melaksanakan KSST dapat menemui hambatan berupa protes, demonstrasi atau penolakan terkait kebijakan tersebut.

Tulisan ini akan berpedoman pada satu pertanyaan penelitan untuk membahas isu mengenai Kerjasama Selatan-Selatan dan Triangular ini. Pertanyaan tersebut adalah Mengapa Indonesia perlu untuk memberikan bantuan luar negeri ke negara sedang berkembang dalam kerangka Kerjasama SelatanSelatan dan Triangular? Apa saja hambatan dan tantangan yang dihadapi Indonesia dalam mengimplementasikan Kebijakan KSST? Tujuan dari penelitian ini adalah memberikan pandangan baru dalam melihat bantuan luar negeri dalam skema KSST sebagai instrumen 
politik bagi pemerintah Indonesia untuk meningkatkan perannya dalam kancah politik global.

\section{Kerangka Pemikiran}

\section{Apa itu Kerjasama Selatan-Selatan dan} Triangular?

Tidak ada definisi tunggal mengenai apa itu Kerjasama Selatan-Selatan. Setiap peneliti ataupun organisasi dalam publikasinya memiliki definisi yang berbeda-beda terkait Kerjasama Selatan-Selatan. Secara sederhana, Kerjasama Selatan-Selatan dapat dipahami sebagai hubungan yang dilakukan oleh dua atau lebih negara-negara sedang berkembang dalam meningkatkan pembangunan. Kakonge menjelaskan secara singkat Kerjasama SelatanSelatan sebagai hubungan antara dan diantara negara sedang berkembang. Secara lebih rinci Kakonge menjelaskan Kerjasama SelatanSelatan sebagai proses dimana dua atau lebih negara sedang berkembang mengejar tujuan pembangunan individu atau kolektif melalui kerjasama berupa pertukaran pengetahuan, keterampilan, sumberdaya, dan kecakapan teknis. ${ }^{1}$ Definisi dari Kokange ini cukup lengkap untuk memberikan pemahaman apa itu Kerjasama Selatan-Selatan dan dapat dipakai sebagai acuan dalam memahami tulisan ini.

\footnotetext{
${ }^{1}$ Kokange, J. O., 2014, The Evolution of South-South Cooperation: A Personal Reflection, Global Policy Essay, July, hlm. 1.
}

Berbeda dengan kerjasama selatan-selatan, kerjasama triangular melibatkan tiga negara atau lebih dengan peran atau posisi yang berbedabeda di masing-masing pihak. Kerjasama Triangular melibatkan tidak hanya negaranegara selatan atau negara sedang berkembang tetapi juga melibatkan negara-negara utara atau negara maju juga institusi multilateral seperti lembaga donor atau organisasi internasional seperti PBB. Peran negara maju melalui lembaga donornya dan institusi multilateral seperti PBB hanya sebagai pendukung saja, inisiatif kerjasama tetap harus dilakukan oleh negaranegara selatan. Skema konfigurasi yang melibatkan negara selatan, negara maju, dan institusi multilateral ini kemudian disebut sebagai kerjasama triangular. ${ }^{2}$ Kerjasama Selatan-Selatan dan Triangular dapat digambarkan melalui gambar di bawah ini.

Gambar 1. Konfigurasi Kerangka Kerjasama Selatan-Selatan dan Triangular

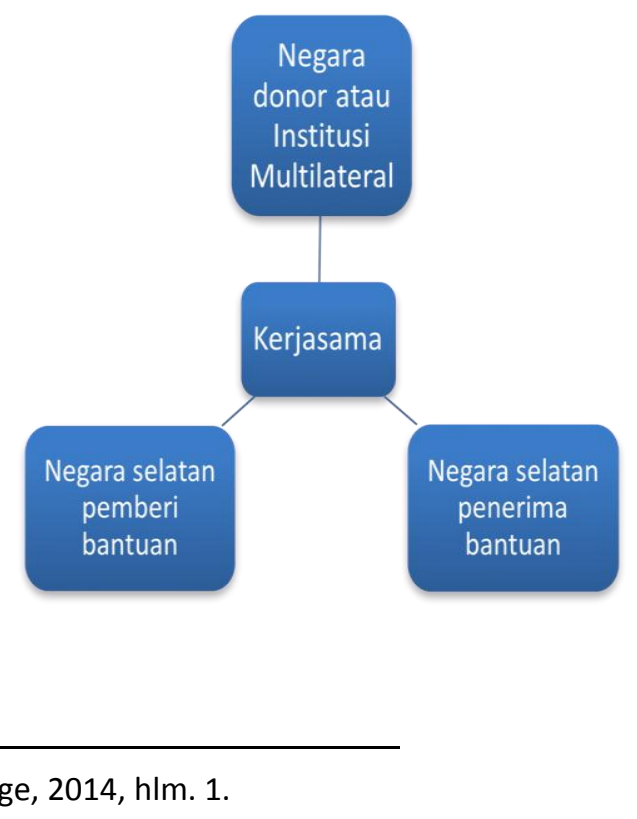


Kerjasama Selatan-Selatan dan Triangular Dalam Kacamata Perspektif LiberalInstitusionalis

Perspektif liberal-institusionalis tentunya dilandasi oleh pemikiran-pemikiran liberal yang memandang bahwa sifat manusia pada dasarnya adalah baik yaitu cinta damai, kooperatif, kompetitif namun kompetisi yang dilakukan dengan cara yang konstruktif, dan melakukan sesuatu berdasarkan suatu alasan bukan hanya emosi. ${ }^{3}$ Perspektif ini memandang manusia secara positif dan dalam mencapai tujuan individu atau kolektif dapat melakukan kerjasama. Hal ini juga diyakini dalam melihat negara sebagai entitas yang bisa melakukan kerjasama. Dalam tulisannya, Mahbubani berpendapat bahwa dengan kerja-sama antar negara, zero sum game dapat berubah menjadi win-win game. ${ }^{4}$ Kurang lebih itu adalah ide dasar dari perspektif liberal-institusionalis

Dalam merumuskan kebijakan luar negeri tentunya semua negara tetap berdasar pada kepentingan nasional. Perspektif liberalinstitusionalis sedikit berbeda dengan perspektif realis dalam memandang konsep kepentingan nasional ini. Perspektif realis melihat kepentingan nasional sebagai pembagian antara insiders dan outsiders, kepentingan siapa yang diakomdasi (negara) dan kepentingan mana yang

\footnotetext{
${ }^{3}$ Balaam, D. N. \& Veseth, M., 2005, Introduction to International Political Economy Third Edition, Prentice Hall, New Jersey, hlm. 48.

${ }^{4}$ Mahbubani, K., 2013, The Great Convergence, Public Affairs, New York, hlm. 145.
}

diabaikan (negara lain). ${ }^{5}$ Anggapan semacam ini kemudian menciptakan kondisi zero sum game dalam dinamika hubungan internasional. Perspektif Liberal Institusionalis dalam melihat dinamika hubungan internasional menerima ide bahwa negara memiliki peran penting dalam kondisi sistem internasional yang anarki, namun penganut paham liberalis institusionalis berargumen bahwa prospek untuk melakukan kerjasama antar negara, bahkan dalam dunia yang anarki tetap ada. Bagi mereka kondisi dunia yang anarki dapat diatasi dengan pembentukan rezim dan kerjasama institusional. ${ }^{6}$

Apabila perspektif ini diaplikasikan dalam memandang fenomena KSST, keputusan Indonesia untuk memberikan bantuan kepada negara sedang berkembang yang lain adalah keputusan yang tepat karena dengan memberikan bantuan, Indonesia telah melakukan mutual gain. Memberikan bantuan tidak hanya memenuhi kepentingan nasional Indonesia saja tetapi juga memenuhi kepentingan kolektif institusi multilateral di mana Indonesia bergabung sebagai anggota di dalamnya. Memberikan bantuan adalah kepentingan kolektif dari PBB juga G20. ${ }^{7}$ Tidak hanya

\footnotetext{
${ }^{5}$ Burchill, S., 2005, The National Interest in International Relations Theory, Palgrave Macmillan, New York, hlm. 27.

${ }^{6}$ Burchill, 2005, hlm. 121.

${ }^{7}$ Kerjasama Selatan-Selatan dan Triangular menjadi salah satu fokus PBB dan dilembagakan menjadi United Nations Office for South-South Cooperation (UNOSSC) sebagai entitas independen pada tahun 1975. Pada forum G20, KSST juga menjadi salah satu fokus dari G20 dan dibentuk Task Team on South-South Cooperation sebagai wadah khusus
} 
negara penerima bantuan yang merasakan peningkatan dalam hal pembangunan tetapi Indonesia sebagai negara yang memberikan bantuan juga merasakan keuntungan dari memberikan bantuan.

\section{Dinamika Kerjasama Selatan-Selatan dan Triangular Indonesia}

Konferensi Asia Afrika (KAA) yang diselenggarakan pada 18 - 24 April 1955 adalah batu pijakan utama terciptanya Kerjasama Selatan-Selatan diantara negara-negara Asia dan Afrika. Indonesia berperan sebagai negara pemrakarsa terselenggaranya KAA yang melibatkan 29 negara. ${ }^{8}$ Sejak saat itu Indonesia berperan aktif dalam memberikan bantuan ke negara-negara sedang berkembang atau sesama negara-negara selatan. Sebelum dikenal istilah Kerjasama Selatan-Selatan seperti sekarang ini, kerjasama negara-negara selatan ini dulu dikenal dengan nama Kerja sama Teknik antar Negara Berkembang (KTNB). Buenos Aires Plan of Action (BAPA) adalah hasil dari Konferensi PBB di Argentina pada tahun 1978, dan dari BAPA ini muncul inisiatif pelaksanaan KTNB. Sejak tahun 1981 Indonesia bekerja sama dengan Japan International Cooperation Agency (JICA) telah banyak memberikan bantuan teknik

untuk membahas isu-isu KSST. Indonesia menjadi Co-Chair dalam Task Force ini.

${ }^{8}$ Museum Konperensi Asia-Afrika, 2016, Sejarah Konferensi Asia Afrika, diakses 6 Agustus 2016, http://asianafricanmuseum.org/sejarah-konferensiasia-afrika/ kepada negara-negara sedang berkembang. ${ }^{9}$ Istilah Kerjasama Selatan-Selatan mulai dikenal sejak keluarnya Resolusi PBB No. 58/220 pada tahun 2003 yang berisi mengenai High Level Committee on South-South Cooperation dan penetapan tanggal 19 Desember sebagai Hari PBB untuk Kerjasama Selatan-Selatan. ${ }^{10}$

Jenis bantuan luar negeri yang diberikan oleh Indonesia sebagian besar bukan dalam bentuk dana tetapi dalam bentuk pengiriman tenaga ahli, memberikan pelatihan pengembangan kapasitas, dan bantuan alat-alat. Negara-negara yang menjadi target penerima bantuan adalah negara-negara Asia, Afrika, Pasifik, dan Amerika Latin. Secara khusus, Palestina menjadi negara priortias penerima bantuan teknis dari Indonesia. Palestina adalah negara yang paling banyak mendapatkan bantuan dari Indonesia, sejak tahun 2006 sampai 2014 saja sudah 1.061 warga palestina mendapatkan bantuan kerjasama Teknik dari Direktorat Kerjasama Teknik. ${ }^{11}$ Sampai pada tahun 2016 ini diperkirakan sudah ada sekitar

\footnotetext{
${ }^{9}$ Kementerian Luar Negeri Republik Indonesia, 2012, Kerjasama Teknik, diakses 5 Agustus 2016, http://www.kemlu.go.id/id/kebijakan/isukhusus/Pages/Kerjasama-Teknik.aspx ${ }^{10}$ Center for East Asian Cooperation Studies (CEACoS), 2010, Studi Arah Kebijakan Indonesia dalam Kerjasama Selatan-Selatan, Center for East Asian Cooperation Studies (CEACoS), Jakarta.

${ }^{11}$ Junida, A., 2014, Palestina Prioritas Penerima Bantuan Teknik Indonesia, diakses 18 Agustus 2016, http://www.antaranews.com/berita/437529/palestin a-prioritas-penerima-bantuan-teknik-indonesia
} 
1.600 warga Palestina yang menerima manfaat dari bantuan teknis yang diberikan oleh Indonesia. $^{12}$ Bantuan teknis yang dimaksud antara lain adalah pembangunan Pusat Jantung Indonesia di Rumah Sakit Al-Shifa, Gaza, Palestina. ${ }^{13}$ Siti Mauludiah, Direktur Kerja Sama Teknik Direktorat Jenderal Informasi dan Diplomasi Publik Kementerian Luar Negeri, menyatakan bahwa Palestina adalah negara prioritas penerima bantuan teknis dari Indonesia dalam hal pembangunan kapasitas karena kepentingan politisnya tinggi. ${ }^{14}$ Beberapa bantuan pengembangan kapasitas yang dimaksud antara lain pelatihan kepada pegawai negeri dan kepolisian negara tersebut. ${ }^{15}$

Kepentingan Politis terhadap Palestina tinggi bagi Indonesia dan hal ini Nampak dalam peringatan 60 tahun KAA yang diselenggarakan di Indonesia pada tahun 2015. Presiden Jokowi mengusung topik kemerdekaan Palestina dalam pertemuan KAA waktu itu. ${ }^{16}$ Hal ini juga sesuai

\footnotetext{
${ }^{12}$ Ardianto, R., 2016, Jadikan Indonesia Negara Donor, diakses 18 Agustus 2016, http://www.koransindo.com $/$ news.php? $r=0 \& n=10 \&$ date $=2016-07$ 03.
}

${ }^{13}$ Detik Finance, 25 September 2013, Ini Bantuan Nyata RI Untuk Palestina, diakses 30 Agustus 2016, http://finance.detik.com/ekonomi-bisnis/2369206/inibantuan-nyata-ri-untuk-palestina

${ }^{14}$ Junida, 2014.

${ }^{15}$ Maulana, V, 3 November 2015, Palestina Tetap Jadi Prioritas Polugri Indonesia, diakses 30 Agustus 2016,

http://international.sindonews.com/read/1058549/40/ palestina-tetap-jadi-prioritas-polugri-indonesia1446549195

${ }^{16}$ Sudiaman, M., 2015, Antara KAA dan Palestina, diakses 18 Agustus 2016, dengan UUD 1945 khususnya bagian pembukaan alinea pertama dan menjadi pedoman dalam melakukan kebijakan luar negeri Indonesia.

\section{"Bahwa sesungguhnya Kemerdekaan itu ialah hak segala bangsa dan oleh sebab itu, maka penjajahan di atas du- nia harus dihapuskan, karena tidak sesuai dengan peri- kemanusiaan dan peri-keadilan.,"17}

Isu kemerdekaan memang menjadi agenda penting yang sudah sejak lama diperjuangakan oleh Indonesia. Oleh karena itu Indonesia mendukung kemerdekaan bagi rakyat Palestina dan isu kemerdekaan Palestina menjadi kepentingan politis Indonesia.

Selain Palestina, beberapa negara yang menjadi prioritas bagi Indonesia adalah Afghanistan, Myanmar, dan Timor Leste. ${ }^{18}$

\footnotetext{
http://www.republika.co.id/berita/kolom/resonansi/15 /04/24/nnb966-antara-kaa-dan-palestina ${ }^{17}$ Negara Republik Indonesia, 1945, Undang-Undang Dasar Negara Republik Indonesia Tahun 1945.

${ }^{18}$ Ardianto, 2016.
} 
Tabel 1.Data Bantuan Indonesia ke Beberapa

Kawasan atau Negara

\begin{tabular}{|c|c|c|c|}
\hline $\begin{array}{l}\text { Kawasan } \\
\text { atau } \\
\text { Negara }\end{array}$ & $\begin{array}{l}\text { Periode } \\
\text { Pelaksanaan } \\
\text { Bantuan }\end{array}$ & $\begin{array}{l}\text { Jumlah } \\
\text { Bantuan }\end{array}$ & $\begin{array}{l}\text { Jumlah } \\
\text { Peserta }\end{array}$ \\
\hline $\begin{array}{l}\text { Kawasan } \\
\text { Asia } \\
\text { Tengah, } \\
\text { Selatan, } \\
\text { dan Barat }\end{array}$ & $2006-2015$ & $\begin{array}{l}92 \text { Program } \\
\text { Pembangunan } \\
\text { Kapasitas }\end{array}$ & $\begin{array}{l}576 \\
\text { peserta }\end{array}$ \\
\hline $\begin{array}{l}\text { Kawasan } \\
\text { ASEAN }\end{array}$ & $2006-2015$ & $\begin{array}{l}76 \text { Program } \\
\text { Pembangunan } \\
\text { Kapasitas }\end{array}$ & $\begin{array}{l}\text { Tidak } \\
\text { ada } \\
\text { data }\end{array}$ \\
\hline $\begin{array}{l}\text { Kawasan } \\
\text { Afrika }\end{array}$ & $2006-2015$ & $\begin{array}{l}93 \text { Program } \\
\text { Pembangunan } \\
\text { Kapasitas }\end{array}$ & $\begin{array}{l}680 \\
\text { peserta }\end{array}$ \\
\hline Palestina & $2006-2015$ & $\begin{array}{l}46 \text { Program } \\
\text { Pembangunan } \\
\text { Kapasitas }\end{array}$ & $\begin{array}{l}1.257 \\
\text { peserta }\end{array}$ \\
\hline $\begin{array}{l}\text { Kawasan } \\
\text { Pasifik }\end{array}$ & $1999-2015$ & $\begin{array}{l}94 \text { Program } \\
\text { Pembangunan } \\
\text { Kapasitas }\end{array}$ & $\begin{array}{l}540 \\
\text { Peserta }\end{array}$ \\
\hline
\end{tabular}

Sumber data: Leaflet Indonesia SSTC Profile \& Info dari Tim Koordinasi Nasional KSST ${ }^{19}$

KSST baru mendapatkan perhatian khusus dari pemerintah sejak dibentuknya Tim Koordinasi

\footnotetext{
${ }^{19}$ National Coordinatioan Team on South-South Cooperation and Triangular of Indonesia, 2015, Indonesia Profile SSTC \& Info, diakses 20 Agustus 2016, http://ssc.indonesia.org/ksst/indexca35.html?page _id $=1208$
}

Nasional pada tahun 2010. ${ }^{20}$ Tim Koordinasi Nasional KSST ini terdiri dari empat kaki yaitu BAPPENAS, Kementerian Luar Negeri, Kementerian Keuangan, dan Kementerian Sekretariat Negara. Tugas utama dari Tim Koordinasi Nasional ini adalah melakukan koordinasi terkait program yang KSST dari Kementerian atau Lembaga, menghubungkan dan memformulasikan kerjasama dengan mitra pembangunan, dan memonitor pelaksanaan program KSST.

$$
\text { Dalam melaksanakan Kerjasama }
$$

Triangular, Indonesia telah bekerja sama dengan berbagai lembaga donor atau organisasi multilateral seperti United Nations Development Program (UNDP), World Bank, Japan International Cooperation Agency (JICA), the Australia Agency for International Development (AUSAID), United States AID (USAID), dan Gesellschaft fur Internationale Zusammenarbeit (GIZ) (Direktorat Kerjasama Teknik, 2012). Dari semua lembaga donor dan organisasi multilateral, JICA adalah mitra utama Indonesia dalam melakukan KSST. JICA sudah berperan aktif sejak tahun 1990an dalam mendukung KSST yang pada waktu itu namanya masih $\mathrm{KTNB}^{21}$

\footnotetext{
${ }^{20}$ National Coordination Team on South-South and Triangular Cooperation of Indonesia, 2015, About SSTC, diakses 25 Agustus 2016, http://sscindonesia.org/ksst/index88b6.html?page_id=1095 ${ }^{21}$ CEACOS, 2010, hlm. 87.
} 


\section{KSST dan Kepentingan Indonesia}

Kepentingan Indonesia di sini tidak dilihat semata hanya kepentingan nasional Indonesia saja yang kemudian membagi kepentingan menjadi dua yaitu insiders (kepentingan nasional) dan outsiders (kepentingan negara lain) yang dapat diabaikan. Pandangan seperti ini dapat menciptakan dinamika hubungan internasional yang mengarah ke zero sum game. Kepentingan Indonesia dapat terpenuhi dengan melakukan kerjasama dengan negara-negara lain sehingga akan tercipta win-win game dalam dinamika hubungan internasional. Dalam konteks Kerjasama Selatan-Selatan dan Triangular tidak hanya penerima bantuan yang mendapatkan keuntungan tetapi Indonesia sebagai pemberi bentuan juga mendapatkan keuntungan.

Kerjasama internasional dalam hal pembangunan salah satunya terwadahi dalam forum G20. Indonesia adalah salah satu anggota dari G20, sebuah organisasi multilateral yang terdiri dari 19 negara dan satu organisasi regional Uni Eropa yang merupakan forum utama dalam membahas kerjasama ekonomi internasional dan reformasi tata kelola pembangunan global. ${ }^{22}$ G20 ini bukan sekedar kelompok biasa karena keanggotaannya terbatas namun memiliki tujuan ambisius untuk

\footnotetext{
${ }^{22}$ G20, 2015, About G20, diakses 30 Agustus 2016, http://www.g20.org/English/aboutg20/AboutG20/201 511/t20151127_1609.html
}

memberikan dampak secara global. ${ }^{23}$ G20 sebagai organisasi multilateral memiliki kepentingan kolektif bersama dan salah satunya adalah terkait Overseas Development Aids (ODA). Isu mengenai ODA ini telah menjadi perhatian khusus dari anggota G20 sejak KTT G20 di London. Dalam KTT G20 tersebut anggota G20 berkomitmen untuk memenuhi target Millenium Development Goals. ${ }^{24}$ KSST kemudian menjadi fokus dari G20 dan pada Konferensi Tingkat Tinggi di Seoul pada tahun 2010 meminta untuk dibentuknya Task Team on South-South Cooperation and Triangular (TTSSTC). ${ }^{25}$

Adanya kebijakan memberikan bantuan dan salah satunya melalui skema KSST ini kemudian menimbulkan pertanyaan, apa untungnya bagi Indonesia dengan memberikan bantuan kepada negara sedang berkembang yang lain? Negara yang menerima bantuan dari Indonesia tentunya dapat menerima manfaat, lalu apa yang didapat oleh Indonesia?

\footnotetext{
${ }^{23}$ Hermawan, Y. P., Sriyuliani, W., Hardjowijono, G. H. \& Tanaga, S., 2010, The Role of Indonesia in the G-20: Background, Role, and Objectives of Indonesia's Membership, Friedrich Ebert Stiftung, DKI Jakarta, hlm. 1-2.

${ }^{24}$ Hermawan, Y. P. \& Kasim, S. I., 2013, Kemenkeu, diakses 30 Agustus 20116 http://www.kemenkeu.go.id/sites/default/files/Komit men\%20Indonesia\%20Untuk\%20ODA_PKPPIM.pdf ${ }^{25}$ UNOSSC, Paragraphs in the 2010 Seoul G20 Summit Document relevant to South-South cooperation (paragraph 51 (i) decision), diakses 30 Agustus 2016, http://ssc.undp.org/content/dam/ssc/documents/HLC $\% 202012 / 6 \% 202010 \% 20$ Seoul\%20G20\%20Summit $\% 20$ Document.pdf
} 
Indonesia sebagai salah satu anggota G20 tentunya perlu untuk mengimplementasikan kepentingan kolektif dari G20 terkait isu pembangunan tersebut. Seperti sudah dibahas pada bagian sebelumnya Indonesia memang telah aktif dalam memberikan bantuan kepada sesama negara sedang berkembang melalui skema KSST. Fordelone menjelaskan bahwa kerjasama pembangunan internasional dewasa ini semakin meningkat seiring dengan semakin meningkatnya peran negara-negara berpenghasilan menengah bukan hanya sebagai penerima bantuan lagi tetapi juga sebagai pemberi bantuan. ${ }^{26}$ Status Indonesia sebagai negara berpendapatan menengah memposisikan Indonesia bukan sebagai negara penerima bantuan saja tetapi juga sebagai negara yang memberikan bantuan.

Dengan mengimplementasikan bantuan pembangunan dalam skema KSST berarti Indonesia sudah turut berperan aktif dalam mewujudkan kepentingan kolektif forum G20. Apalagi Indonesia dipercaya sebagai Co-Chair dalam TT-STC. Berarti Indonesia berada di garis terdepan dalam menangani isu KSST di G20. ${ }^{27}$ Selain itu Indonesia juga bisa menunjukkan dirinya sebagai salah satu middle income countries dan menjadi kekuatan baru khususnya dalam isu pembangunan dan ODA. Dalam

\footnotetext{
${ }^{26}$ Fordelone, T. Y., 2009, Triangular Co-operation and Aid Effectiveness, OECD, hlm. 6.

${ }^{27}$ IFAD, Desember 2014, South-South and Triangular Cooperation, diakses 25 Agustus 2016, http://ssc.undp.org/content/dam/ssc/documents/news/ 2014/sstc_web.pdf, hlm. 4.
}

mengimplementasikan KSST Indonesia juga bekerjasama dengan kekuatan ekonomi besar lainnya yang tergabung dalam G20 misalnya Jepang (JICA), Australia (AUSAID) dan Amerika Serikat (USAID).

Jangan dibayangkan bahwa Indonesia memberikan bantuan ke luar negeri dalam bentuk uang, meskipun ada bantuan dalam bentuk uang tetapi bantuan yang diberikan sebagian besar bukan dalam bentuk uang. Dalam memberikan bantuan luar negeri dalam skema KSST Indonesia bantuan yang diberikan sebagian besar adalah dalam bentuk pengiriman tenaga ahli, memberikan pelatihan pengembangan kapasitas, dan bantuan alat-alat. Meskipun bukan dalam bentuk uang namun bantuan semacam itu tetap dapat disebut sebagai bantuan luar negeri karena masing-masing bantuan memiliki nilai. Misalnya saja tenaga ahli tentu saja dalam memberikan transfer kapasitas ada biaya yang dikeluarkan. Dengan memberikan bantuan tenaga ahli apabila pelatihan berhasil tentunya negara yang mendapat bantuan akan menggunakan jasa tenaga ahli lagi dari Indonesia.

Indonesia juga memberikan bantuan berupa alat-alat. Salah satu alat yang pernah diberikan oleh Indonesia adalah bantuan traktor tangan yang diberikan ke negara Vanuatu. Tercatat pada tanggal 10 Februari 2014 Indonesia memberikan bantuan traktor tangan sejumlah 25 unit kepada Vanuatu untuk 
meningkatkan produktivitas pertanian. ${ }^{28}$ Meskipun memberikan bantuan alat tetapi Indonesia dapat menerima manfaat untuk kedepannya. Traktor yang diberikan adalah traktor buatan dalam negeri sehingga jika penggunaan traktor berhasil dan sesuai untuk meningkatkan produktivitas pertanian di Vanuatu ada kemungkinan pemerintah Vanuatu akan membeli traktor dari Indonesia. Memberikan bantuan juga dapat dimanfaatkan sebagai sarana untuk memperkenalkan produk dalam negeri ke luar negeri.

Melalui bantuan luar negeri Indonesia juga dapat menjalin hubungan baik dengan negara penerima bantuan. Sebagian negara penerima bantuan adalah pasar non-tradisional Indonesia. Maksud dari pasar non-tradisional adalah mitra dagang baru yang sebelumnya belum menjadi prioritas bagi perdagangan Indonesia seperti pasar Eropa, Amerika Serikat, dan Jepang. Hubungan baik yang dibina melalui KSST ini dapat juga dimanfaatkan untuk meningkatkan hubungan perdagangan bilateral dengan negara penerima bantuan KSST. Saat memberikan bantuan, mungkin kondisi perekonomian negara penerima bantuan dari Indonesia seperti negara-negara di Afrika misalnya belum maju tetapi ada potensi negaranegara Afrika akan maju perekonomiannya.

\footnotetext{
${ }^{28}$ Bhaskara, H., 2014, Indonesia Berikan Bantuan Traktor Tangan Untuk Vanuatu, diakses 28 Agustus 2016, http://internasional.kompas.com/read/2014/02/11/123 3030/Indonesia.Beri.Bantuan.Traktor.Tangan.untuk. Vanuatu
}

Menurut Siti Saat ini Afrika sedang menggeliat dalam sektor ekonomi. ${ }^{29}$ Meskipun ekspor Indonesia ke pasar non-tradisional seperti negara-negara Afrika Subsahara, Amerika Latin dan Tengah secara volume dan nilanya masih kecil namun grafiknya terus meningkat. ${ }^{30}$

Dengan KSST ternyata Indonesia telah menciptakan mutual gain bagi negara penerima bantuan juga bagi kepentingan Indonesia sendiri. Tidak hanya itu, dengan KSST Indonesia juga turut mendukung pencapaian kepentingan kolektif dari negara-negara yang bekerja sama dan tergabung dalam satu institusi multilateral dalam contoh kasus yang dibahas dalam tulisan ini adalah G20.

\section{Hambatan dan Tantangan Implementasi Kebijakan KSST}

Bantuan luar negeri dalam kerangka KSST memang bukan isu baru bagi Indonesia dan memang sudah banyak sekali program bantuan berupa pembangunan kapasitas melalui rangkaian pelatihan sudah dilakukan Indonesia. Sayangnya pengimplementasian bantuan luar negeri dalam kerangka KSST ini masih lemah dalam pendokumentasian. Sulit sekali mencari informasi secara lengkap terkait banyaknya

\footnotetext{
${ }^{29}$ Ade, 2014, Sudah Untungkah Indonesia Beri Bantuan ke Afrika?, diakses 30 Agustus 2016, http://internasional.kompas.com/read/2014/02/11/123 3030/Indonesia.Beri.Bantuan.Traktor.Tangan.untuk. Vanuatu

${ }^{30}$ Tim Koordinasi Nasional KSST, 2016. Mendorong Pembentukan Pakta Perdagangan Selatan-Selatan, diakses 29 Agustus 2016, http://sscindonesia.org/ksst/indexfe02.html?news=mendorongpembentukan-pakta-perdagangan-selatan-selatan
} 
program bantuan yang telah diberikan Indonesia, dana yang dikeluarkan oleh Indonesia, peserta yang terlibat, dan kemana saja bantuan tersebut didistribusikan. Pendokumentasian atau pendataan yang tidak lengkap dan tersebar di masing-masing Kementerian dan Lembaga tentunya akan mempengaruhi kefektifan bantuan luar negeri yang diberikan oleh Indonesia. Perumusan arah kebijakan bantuan luar negeri Indonesia bisa menjadi tidak jelas tanpa pendataan yang lengkap. Data yang lengkap dapat membantu proses evaluasi bantuan luar negeri dan dapat menjadi acuan kedepan dalam merumuskan kebijakan bantuan luar negeri dalam Kerangka KSST.

Saat ini sudah ada Tim Koordinasi Nasional yang terdiri dari empat kaki yaitu Kementerian Luar Negeri, Kementerian Keuangan, Sekretariat Negara dan Bappenas yang dibentuk pada tahun 2014. Meskipun sudah ada Tim Koordinasi Nasional, ternyata pengumpulan informasi terkait bantuan luar negeri dari masing-masing Kementerian dan Lembaga masih sulit dilakukan. Sebagai contoh nyata ketika membuka website Tim Koordinasi Nasional, sampai pada tulisan ini dibuat belum ada data yang terintegrasi secara rapih mengenai bantuan luar negeri yang sudah diberikan Indonesia. Apabila melihat kembali Tabel 1. Maka akan nampak bahwa dalam website Tim Koordinasi Nasional tersebut hanya menyebutkan bantuan yang sudah diberikan per kawasan, bukan per negara. Selain itu juga data hanya ada dari tahun 2006 saja. Belum ada data dari tahun-tahun sebelumnya. Informasi terkait dana yang dikeluarkan oleh Indonesia dalam memberikan bantuan ke luar negeri juga belum terintegrasikan dengan baik.

Hal yang menyebabkan sulitnya pengumpulan informasi melalui Tim Koordinasi Nasional ini adalah kekuatan hukum yang melandasi Tim Koordinasi Nasional masih lemah. Pembentukan Tim Koordinasi Nasional ini berdasarkan Peraturan Menteri saja. Oleh karena itu Tim Koordinasi Nasional KSST kesulitan untuk memaksa Kementerian dan Lembaga yang melaksanakan KSST untuk mengumpulkan informasi. Perlu adanya Peraturan yang lebih tinggi sehingga bisa memaksa Kementerian dan Lembaga untuk aktif mengumpulkan informasi terkait kegiatan KSST yang dilaksanakan.

Belum ada single agency yang menjadi pusat koordinasi Kementerian dan Lembaga dalam memberikan bantuan ke luar negeri. Hal ini mengakibatkan tidak adanya koordinasi antara Kementerian dan Lembaga terkait sehingga memungkinkan terjadinya overlapping dan masing-masing-masing Kementerian dan Lembaga menjalankan kebijakan bantuan KSST sendiri-sendiri. Jika masing-masing Kementerian dan lembaga menjalankan bantuan KSST sendiri-sendiri maka perlu dipertanyakan lagi apakah ini bantuan dalam kerangka KSST ini menjadi instrumen Kebijakan Luar Negeri 
Indonesia atau instrument kebijakan masingmasing Kementerian dan Lembaga.

Tanggapan masyarakat tentunya akan berbeda-beda dalam menanggapi kebijakan bantuan melalui kerangka KSST ini. Tidak semua masyarakat setuju Indonesia memberikan bantuan ke negara lain mengingat kondisi perekonomian di dalam negeri masih belum stabil terlebih masyarakat di daerah pinggiran yang pembangunannya masih tertinggal. Ketimpangan pembangunan juga masih besar di Indonesia. Saat ini mungkin isu ini belum heboh dan menjadi perhatian banyak masyarakat karena memang informasi mengenai KSST ini masih sangat terbatas. Bila Indonesia sudah berkomitmen dengan kebijakan KSST, kedepannya jumlah bantuan akan semakin banyak dan dana yang akan dikeluarkan juga meningkat. Oleh karena itu perlu ada edukasi dan sosialisasi ke masyarakat tentang KSST ini supaya kebijakan ini dapat diterima oleh masyarakat. Edukasi dan sosialisasi ini penting agar masyarakat tahu bahwa kebijakan ini dapat memberikan dampak positif bagi Indonesia dan tentunya masyarakat Indonesia.

\section{Kesimpulan dan Rekomendasi Kebijakan}

Indonesia perlu untuk memberikan bantuan luar negeri melalui skema KSST karena melalui KSST ini Indonesia telah memberikan kontribusi positif bagi pencapaian kepentingan kolektif terkait isu kesejahteraan global. Isu pembangunan merupakan isu universal dan menjadi perhatian institusi multilateral seperti G20 dimana Indonesia tergabung di dalamnya. Peran aktif Indonesia akan memberikan keuntungan politik bagi Indonesia kedepannya karena kehadiran Indonesia di institusi multilateral seperti G20 akan diperhitungkan. Selain itu dengan melakukan KSST, Indonesia telah menciptakan mutual gain baik untuk Indonesia sendiri atau negara penerima bantuan. Bagi Indonesia KSST dapat mempererat hubungan dengan negara penerima bantuan, hubungan baik dapat dimanfaatkan untuk meningkatkan kerjasama perdagangan.

Keuntungan tidak didapat dalam jangka pendek tetapi akan didapat dalam jangka panjang. Terkait permasalahan dan tantangan, dalam implementasi KSST yang perlu menjadi perhatian pemerintah dan pemangku kepentingan terkait adalah isu mengenai koordinasi, pencatatan bantuan, dan tanggapan kontra masyarakat terkait pemberian bantuan keluar negeri.

\section{Rekomendasi kebijakan:}

- Peningkatan koordinasi antar Kementerian dan Lembaga dapat ditingkatkan dengan membentuk Single Agency, sebuah wacana yang memang sudah sering dibahas dalam seminar ataupun diseminasi hasil penelitian terkait KSST. Wacana tanpa komitmen dan dukungan penuh dari pemerintah hanya akan membawa isu ini jalan di tempat. Upaya pembentukan single 
agency merupakan tujuan jangka panjang, tujuan jangka pendek untuk meningkatkan koordinasi bisa diupayakan melalui optimalisasi Tim Koordinasi Nasional untuk Kerjasama Selatan-Selatan.

- Data mengenai bantuan luar negeri masih tersebar di masing-masing Kementerian dan Lembaga terkait. Perlu ada upaya untuk memulai pencatatan bantuan luar negeri yang diberikan oleh Indonesia. Info ini perlu untuk menyusun kebijakan bantuan luar negeri kedepannya supaya tidak terjadi overlapping antar Kementerian dalam memberikan bantuan luar negeri. Data juga penting untuk kepentingan penelitian guna memberikan rekomendasi kebijakan kedepannya.

- Pemerintah perlu secara intensif memberikan edukasi atau sosialisasi kepada masyarakat mengenai pentingnya Indonesia aktif memberikan bantuan luar negeri melalui skema KSST ini. Hal ini diperlukan untuk meminimalisir tanggapan negatif

\section{DAFTAR PUSTAKA}

Ade, 2014, Sudah Untungkah Indonesia Beri Bantuan ke Afrika?, diakses 30 Agustus 2016, http://internasional.kompas.com/read/20 14/02/1 1/1233030/Indonesia.Beri.Bantu an.Traktor.Tangan.untuk.Vanuatu masyarakat Indonesia terkait KSST. Perlu ada penjelasan terkait manfaat yang didapat oleh Indonesai dengan melakukan KSST ini. Edukasi dan sosialisasi bisa dilakukan melalui artikel di media massa, televisi, atau seminar dan diseminasi hasil penelitian.

- Sebagai Co-Chair TT-SSTC di G20 Indonesia berada di garis terdepan untuk membahas KSST. Dengan posisi ini Indonesia dapat menjadi jembatan bagi negara-negara selatan dan negara-negara Utara yang tergabung dalam G20. Permasalahan pembangunan negaranegara selatan dapat diangkat dalam forum diskusi di TT-SSTC dimana banyak negara utara atau negara maju ada dalam forum G20 ini. Negaranegara maju tentunya memiliki sumber daya yang dapat dialirkan ke negaranegara selatan. Indonesia perlu menjaring informasi terkait kebutuhan yang diperlukan di negara-negara selatan sehingga bantuan yang diberikan dalam skema KSST tepat sasaran dan tepat guna.
Ardianto, R., 2016, Jadikan Indonesia Negara Donor, diakses 18 Agustus 2016, http://www.koransindo.com $/$ news.php? $\mathrm{r}=0 \& \mathrm{n}=10 \&$ date $=2$ 016-07-03 
Balaam, D. N. \& Veseth, M., 2005, Introduction to International Political Economy Third Edition, Prentice Hall, New Jersey.

Bhaskara, H., 2014, Indonesia Berikan Bantuan Traktor Tangan Untuk Vanuatu, diakses 28 Agustus 2016, http://internasional.kompas.com/read/20 14/02/11/1233030/Indonesia.Beri.Bantu an.Traktor.Tangan.untuk.Vanuatu

Burchill, S., 2005, The National Interest in International Relations Theory, Palgrave Macmillan, New York

Center for East Asian Cooperation Studies (CEACoS), 2010, Studi Arah Kebijakan Indonesia dalam Kerjasama SelatanSelatan, Center for East Asian Cooperation Studies (CEACoS), Jakarta.

Detik Finance, 25 September 2013, Ini Bantuan Nyata RI Untuk Palestina, diakses 30 Agustus 2016 , http://finance.detik.com/ekonomibisnis/2369206/ini-bantuan-nyata-riuntuk-palestina

Direktorat Kerjasama Teknik, 2012, Indonesia Undang Mitra Pembangunan Untuk Dukung Program Kerjasama Triangular, diakses 20 Agustus 2016, http://www.kemlu.go.id/id/berita/siaranpers/Pages/Indonesia-Undang-MitraPembangunan-Untuk-Dukung-ProgramKerjasama-Triangular.aspx

Fordelone, T. Y., 2009, Triangular Cooperation and Aid Effectiveness, OECD.

G20, 2015, About G20, diakses 30 Agustus 2016 http://www.g20.org/English/aboutg20/A boutG20/201511/t20151127_1609.html

Hermawan, Y. P., Sriyuliani, W., Hardjowijono, G. H. \& Tanaga, S., 2010, The Role of Indonesia in the G-20: Background, Role, and Objectives of Indonesia's Membership, Friedrich Ebert Stiftung, DKI Jakarta.
Hermawan, Y. P. \& Kasim, S. I., 2013, Kemenkeu, diakses 30 Agustus 20116 http://www.kemenkeu.go.id/sites/default /files/Komitmen\%20Indonesia\%20Untu k\%20ODA_PKPPIM.pdf

IFAD, Desember 2014, South-South and Triangular Cooperation, diakses 25 Agustus 2016, http://ssc.undp.org/content/dam/ssc/doc uments/news/2014/sstc_web.pdf

Junida, A., 2014, Palestina Prioritas Penerima Bantuan Teknik Indonesia, diakses 18 Agustus 2016, http://www.antaranews.com/berita/4375 29/palestina-prioritas-penerima-bantuanteknik-indonesia

Kokange, J. O., 2014, The Evolution of SouthSouth Cooperation: A Personal Reflection, Global Policy Essay, July.pp. 1-6.

Kementerian Luar Negeri Republik Indonesia, 2012, Kerjasama Teknik, diakses 5 Agustus 2016, http://www.kemlu.go.id/id/kebijakan/isu -khusus/Pages/Kerjasama-Teknik.aspx

Mahbubani, K., 2013, The Great Convergence, Public Affairs, New York.

Maulana, V, 3 November 2015, Palestina Tetap Jadi Prioritas Polugri Indonesia, diakses $\quad 30 \quad$ Agustus 2016, http://international.sindonews.com/read/ 1058549/40/palestina-tetap-jadiprioritas-polugri-indonesia-1446549195

Museum Konperensi Asia-Afrika, 2016, Sejarah Konferensi Asia Afrika, diakses 6 Agustus 2016, http://asianafricanmuseum.org/sejarahkonferensi-asia-afrika/

National Coordinatioan Team on South-South Cooperation and Triangular of Indonesia, 2015, Indonesia Profile SSTC \& Info, diakses 20 Agustus 2016, http://ssc.indonesia.org/ksst/indexca35.h tml?page_id=1208 
National Coordination Team on South-South and Triangular Cooperation of Indonesia, 2015, About SSTC, diakses 25 Agustus 2016, http://sscindonesia.org/ksst/index $88 \mathrm{~b} 6 . \mathrm{html}$ ?page _id=1095

Negara Republik Indonesia, 1945, UndangUndang Dasar Negara Republik Indonesia Tahun 1945.

Sudiaman, M., 2015, Antara KAA dan Palestina, diakses 18 Agustus 2016, http://www.republika.co.id/berita/kolom /resonansi/15/04/24/nnb966-antara-kaadan-palestina
Tim Koordinasi Nasional KSST, 2016. Mendorong Pembentukan Pakta Perdagangan Selatan-Selatan, diakses 29 Agustus 2016,http://sscindonesia.org/ksst/indexfe02.html?news =mendorong-pembentukan-paktaperdagangan-selatan-selatan

UNOSSC, Paragraphs in the 2010 Seoul G20 Summit Document relevant to SouthSouth cooperation (paragraph 51 (i) decision), diakses 30 Agustus 2016, http://ssc.undp.org/content/dam/ssc/doc uments/HLC\%202012/6\%202010\%20S eoul\%20G20\%20Summit\%20Document .pdf 